\title{
Distribution of lead in body fluids after ingestion of soft solder
}

\author{
W I MANTON' AND C R MALLOY ${ }^{2}$ \\ From the Department of Geology,' The University of Texas at Dallas, Richardson, Texas 75080, and the \\ Department of Internal Medicine, ${ }^{2}$ University of Texas Health Science Center at Dallas, Dallas, Texas 75235 , \\ USA
}

ABSTRACT Blood, serum, cerebrospinal fluid, and urine obtained from a patient before and after chelation therapy showed that $(1)$ the ratio of $\mathrm{Pb}$ in his cerebrospinal fluid to that in his serum varied from 0.4 to 0.9 and was independent of serum $\mathrm{Pb}$ concentration; (2) the fraction of $\mathrm{Pb}$ in his serum fell linearly with decreasing blood $\mathrm{Pb}$ concentration and changed from $1.6 \%$ to $0.33 \%$ as his blood $\mathrm{Pb}$ concentration changed from $116 \mu \mathrm{g} / \mathrm{dl}(5.6 \mu \mathrm{mol} / \mathrm{l})$ to $31 \mu \mathrm{g} / \mathrm{dl}(1.5 \mu \mathrm{mol} / \mathrm{l}) ;$ and (3) his renal clearance of $\mathrm{Pb}$ from serum varied from $5 \mathrm{ml} / \mathrm{min}$ to $36 \mathrm{ml} / \mathrm{min}$. This high value was obtained 11 days after chelation and is attributed to large quantities of $\mathrm{Sn}$ in his urine promoting the excretion of $\mathrm{Pb}$. Solder was identified in his stool after discovery of radio-opaque material in his bowel. The $\mathrm{Pb}$ isotope ratios of the solder were different from those in his urine when he was first admitted, and showed that he had ingested solder when he had returned home on weekend passes.

In the study of the human metabolism of $\mathrm{Pb}$ the precise, isotope ratio measuring mass spectrometer has been little used, but is none the less a valuable and versatile instrument. Recent work includes the study of $\mathrm{Pb}$ kinetics by oral administration of stable isotopes to healthy subjects, ${ }^{1}$ the identification of the endogenous and exogenous components of $\mathrm{Pb}$ in blood through the natural variations in $\mathrm{Pb}$ isotope ratios, ${ }^{2}$ and, by way of the technique of stable isotope dilution, the first accurate measurements of $\mathrm{Pb}$ in serum and cerebrospinal fluid. ${ }^{3}$ We report here an unusual case of $\mathrm{Pb}$ poisoning in which we used these mass spectrometric techniques.

\section{Case history}

The patient was a 60-year-old white man who complained of the abrupt onset of vertigo, slurred speech, and decreased sensation on the right side of his body. For the past two years his work as a plumber had included soldering and grinding soldered joints on copper pipe to a smooth finish. In January 1979 he left his job because of respiratory complaints attributed to bronchitis. When he developed neurological symptoms he was referred for

Received 4 January 1982

Accepted 1 March 1982 evaluation. He had smoked one packet of cigarettes a day for 40 years. His ethanol consumption was under $200 \mathrm{ml}$ a week, and he always drank commercially distilled products. There was no history of hypertension, transient ischaemic attacks, headaches, nausea, or abdominal or seizure disorder. He was not taking any medicine.

Blood pressure was $166 / 90$. He was a slender, alert, and co-operative man. Oral hygiene was poor, and the gingival margin was normal. There were no cutaneous signs of liver disease. Anteroposterior chest diameter was increased, and the cardiac examination showed nothing abnormal. The abdomen was soft without tenderness or masses, and the stool was guaiac negative. Neurological examination was remarkable for a mild right facial weakness (consistent with a central VII paresis), mild peripheral sensory neuropathy affecting his legs, and right-sided loss of temperature and pinprick sensation below the neck. There was no wrist or foot drop. The chest $x$-ray film was consistent with a chronic obstructive pulmonary disease, and initial abdominal films showed nothing abnormal. The serum $\mathrm{K}^{+}$was $4.7 \mathrm{meq} / \mathrm{l}$ and the creatinine $1.2 \mathrm{mg} / 100$ $\mathrm{ml}$. Serum aspartate transaminase (SGOT), lactate dehydrogenase, alkaline phosphatase, and bilirubin were normal. The haematocrit was $43.5 \%$ and there was no basophilic stippling of the red cells. Urine analysis showed nothing abnormal. Twenty-four- 
hour urine coproporphyrin was $1 \cdot 17 \mathrm{mg} / 24 \mathrm{~h}$ (normal range $100-300 \mu \mathrm{g} / 24 \mathrm{~h}$ ). Delta-aminolaevulinic acid screen was "moderately positive," but a repeat sample was negative. The initial computed tomogram (9 May 1979) showed a small arcuate region of low density in the left basal ganglia affecting the junction of the anterior and posterior limbs of the internal capsule. Electroencephalography showed nothing abnormal. Before a lumbar puncture performed as part of his routine evaluation the patient volunteered to be a control in a study of cerebrospinal fluid lead content in patients with amyotrophic lateral sclerosis. The study was approved by the appropriate committee of the University of Texas at Dallas. A repeat computed tomogram (3 July 1979) again showed the small low density region adjacent to the left internal capsule, which was thought to represent an area of lacunar infarction.

Initial cerebrospinal fluid, blood, serum, and urine $\mathrm{Pb}$ concentrations were raised. Six weeks later they had increased by $50 \%$ (table). The clinical impression was cerebrovascular disease and coexistent lead intoxication. Treatment with calcium disodium ethylenediaminotetra-acetate (EDTA) $(3000 \mathrm{mg}$ intravenously over 10 hours) was started. Because the calcium salt of EDTA was not a formulary item, and therefore not available at all times, tetrasodium EDTA was substituted when needed. During the initial infusions serum $\mathrm{Ca}$ was monitored and did not change appreciably. During and after treatment $\mathrm{Pb}$ concentrations in urine, blood, serum, and cerebrospinal fluid were monitored. To determine the source of $\mathrm{Pb}$ intoxication, the isotope ratios of the $\mathrm{Pb}$ were measured. When it became apparent that the source was solder, an attempt was made to measure the patient's excretion of Sn. The results and their importance are discussed below.

The patient was treated daily for five days and sent home for the weekends for a total of 15 treatments with EDTA. After the second week the patient returned from home and complained of vague abdominal discomfort. An abdominal $x$-ray examination on the seventeenth day of treatment showed fine metal-density particles scattered throughout the colon. A repeat $x$-ray examination (day 20) showed nearly complete disappearance of the particles. His stool collected during this period contained particles that were identified as solder.

In May 1980 neurological examination was remarkable only for diminished vibratory sense in the legs. Blood $\mathrm{Pb}$ was $31 \mu \mathrm{g} / \mathrm{dl}(1.5 \mu \mathrm{mol} / \mathrm{l})$. In October 1980 he suddenly developed aphasia and he fell once to the right. Aphasia resolved after two days, and examination at that time was remarkable for diminished vibratory sense in the arms and legs, mild ataxia, and poor performance of cerebellar testing in the legs. Blood $\mathrm{Pb}$ was $83 \mu \mathrm{g} / \mathrm{dl}(4.0 \mu \mathrm{mol} / \mathrm{l})$, and a repeat course of chelation therapy (with penicillamine) was administered.

\section{Material and methods}

LEAD ASSAYS

A $30 \mathrm{~cm}$ radius, $60^{\circ}$ sector field mass spectrometer, and a clean chemical laboratory were used in this work. To measure $\mathrm{Pb}$ concentrations, we took $5 \mathrm{ml}$ of blood, $10 \mathrm{ml}$ of serum and cerebrospinal fluid, and $10-200 \mathrm{ml}$ of urine, added a pure ${ }^{206} \mathrm{~Pb}$ spike and decomposed by boiling with conc $\mathrm{HNO}_{3}$ in Teflon FEP bottles. For blood and urine, the mixture of $\mathrm{Pb}$ isotopes was separated by $\mathrm{Ba}\left(\mathrm{NO}_{3}\right)_{2}$ coprecipitation and electrodeposition ${ }^{2}$; for serum and cerebrospinal fluid, separation was by ion exchange, using the same resin and columns as used for $\mathrm{Sn}$ (see below), except that the sample was loaded in and the column washed by $1 \cdot 2 \mathrm{~N} \mathrm{HCl}$. The $\mathrm{Pb}$ was stripped with $6 \mathrm{~N} \mathrm{HCl}$. A

Summary of $\mathrm{Pb}$ and Sn concentrations in body fluids before and after chelation therapy

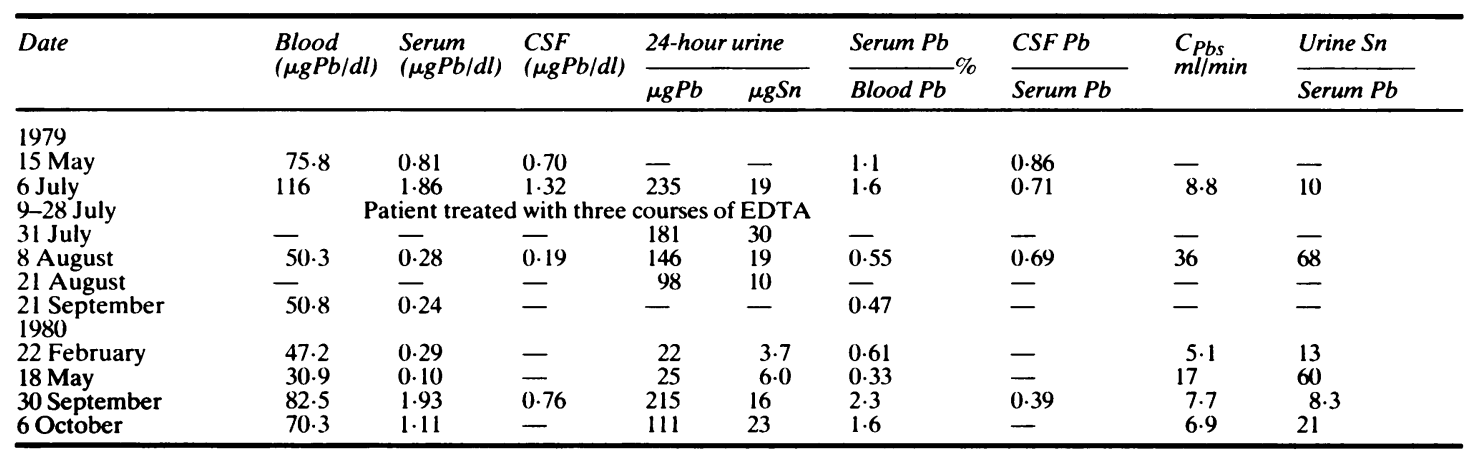

$\mathrm{C}_{\mathrm{Pbs}}=$ Clearance of $\mathrm{Pb}$ from serum. 
large amount of organic material not decomposed by $\mathrm{HNO}_{3}$ follows $\mathrm{Pb}$ through the column and has to be destroyed by $\mathrm{HClO}_{4}$. From the amount of crystalline residue this material clearly contains much complexed metal, but this does not interfere with the quality of the ionisation of $\mathrm{Pb}$ needed for acceptable stable isotope dilution runs. (Similar material greatly suppressed the ionisation of $\mathrm{Sn}$, however, necessitating that all the organic material be destroyed before the ion exchange separation.) For the isotope ratio runs an aliquot of urine containing 1 $\mu \mathrm{g}$ of $\mathrm{Pb}$ was processed through the ion exchange columns and the $\mathrm{Pb}$ was further purified by electrodeposition. We report only the ratio of ${ }^{206} \mathrm{~Pb} /$ ${ }^{2017} \mathrm{~Pb}$ which, being close to unity, is the most accurately measured. The relative standard deviation averaged $0.06 \%$. Blanks ranged from 1 to $2 \mathrm{ng} \mathrm{Pb}(5$ to $10 \mathrm{pmol}$ ), negligible in the case of blood and urine, but not more than $10 \%$ of the $\mathrm{Pb}$ processed in serum and cerebrospinal fluid.

TIN ASSAYS

We found that $\mathrm{Sn}$ is ionised from an emitter of silica gel and phosphoric acid on an Re filament and that 1 $\mu \mathrm{g} \mathrm{Sn}(8 \mathrm{nmol})$ gives an ion current of about 10 picoamps stable for 20 minutes. Ions of $\mathrm{RhO}$ are always present and interfere at mass 119 . We therefore used a $97.8 \%$ enriched ${ }^{118} \mathrm{Sn}$ spike and measured the ratio ${ }^{120} \mathrm{Sn} / /^{18} \mathrm{Sn}$. Urine was first decomposed in $70 \% \mathrm{HNO}_{3}$. An aliquot of $1 \%-2 \%$ of the daily output was spiked with $1 \mu \mathrm{g}{ }^{118} \mathrm{Sn}(8 \mathrm{nmol})$ and dried in a Teflon capsule. To prevent hydrolysis of Sn salts to intractably insoluble metastannic acid, the drying was carried out under a heat lamp. Five hundred microlitres of $\mathrm{HClO}_{4}$ containing $0.25 \%$ $\mathrm{H}_{2} \mathrm{SO}_{4}$ were added to the residue, and the capsule was sealed with a tight-fitting lid containing an $0.4 \mathrm{~mm}$ diameter weep hole. The temperature was held at $180^{\circ} \mathrm{C}$ for 48 hours, by which time the oxidation of the organic residue was complete. If $\mathrm{H}_{2} \mathrm{SO}_{4}$ was not added more than $90 \%$ of the $\mathrm{Sn}$ was lost by volatilisation. $\mathrm{ClO}_{4}$ ions, which have almost infinite binding coefficients with anion exchange resin, were removed as insoluble $\mathrm{KClO}_{4}$ by adding $4 \mathrm{mmol}$ of $\mathrm{KCl}$ for each per cent of the daily output in the aliquot. The sample was dried, dissolved in $2 \mathrm{ml}$ of $6 \mathrm{~N} \mathrm{HCl}$, centrifuged, and the supernatant was loaded on to an ion exchange column of Teflon, $6.3 \mathrm{~mm}$ diameter, containing Dowex $1 \times 8,200-400$ mesh to a height of $16 \mathrm{~mm}$. After draining, the column was washed with three $0.5 \mathrm{ml}$ portions of $6 \mathrm{~N} \mathrm{HCl}$, followed by three 0.5 $\mathrm{ml}$ portions of $8 \mathrm{~N} \mathrm{HF}$. Sn is retained on the column as the hexafluoride ion and is removed with $2 \mathrm{ml}$ of $2 \mathrm{~N}$ $\mathrm{HNO}_{3}$. The blank for this procedure is about $1 \mathrm{ng}(8$ pmol). Small amounts of $\mathrm{Cd}$ follow $\mathrm{Sn}$. These are usually not a problem and burn off the filament while
$\mathrm{Sn}$ is ionising. When the patient was on chelation therapy, however, his urine contained so much Cd that sufficiently large amounts followed Sn so as to almost completely suppress its ionisation. We lost the majority of these runs, even though we put some samples through the ion exchange column twice.

\section{Results}

Before chelation, his urinary excretion of $\mathrm{Sn}$ and $\mathrm{Pb}$ averaged 20 and $230 \mu \mathrm{g} / 24 \mathrm{~h}$, respectively. The ${ }^{206 \mathrm{~Pb} /}$ ${ }^{207} \mathrm{~Pb}$ ratio was constant at $1 \cdot 171$ (fig 1 ). On the first day of chelation (day 1$)$ he excreted $12 \mathrm{mg} \mathrm{Pb}(0.58$ $\mathrm{mmol}$ ) and, with the exception of day 5 , successively less on the succeeding five days. A small shift in isotope ratio was seen after day 1 . His blood $\mathrm{Pb}$ initially increased to $123 \mu \mathrm{g} / \mathrm{dl}(5.9 \mu \mathrm{mol} / \mathrm{l})$ but fell to $45 \mu \mathrm{g} / \mathrm{dl}(2.2 \mu \mathrm{mol} / \mathrm{l})$ by day 5 . On days 7 and 8 , the weekend, the patient went home. The $\mathrm{Pb}$ content of his urine continued to decrease, but that of Sn increased. His isotope ratio attained the baseline value on day 7 but increased on day 8 . Blood drawn the following morning, before resumption of chelation therapy, showed that the isotope ratio of the $\mathrm{Pb}$ in his body was rapidly changing. Except for a decline on day 10 the ratio in his urine increased to a maximum of 1.192 on day 12 . It then declined until day 14 , the first day of the following weekend when the patient again went home. On day 15 , the Sunday, the isotope ratio of his urine increased and the following morning his blood $\mathrm{Pb}$ stood at $70 \mu \mathrm{g} / \mathrm{dl}(3.4$ $\mu \mathrm{mol} / \mathrm{l})$. On day 17 , when solder was discovered in his bowel, the isotope ratio of $\mathrm{Pb}$ in his urine was again at a maximum value of $1 \cdot 192$. That of the solder was $1 \cdot 197$. During the three-day passage of the solder through his colon the isotope ratio and quantity of $\mathrm{Pb}$ in his urine declined. At the end of treatment his blood $\mathrm{Pb}$ had been halved and his serum and cerebrospinal fluid $\mathrm{Pb}$ reduced by a factor of nearly 7 . Over the next six months his blood and serum $\mathrm{Pb}$ remained constant, while his urinary excretion of $\mathrm{Pb}$ and Sn declined appreciably. By May 1980 his blood $\mathrm{Pb}$ had fallen to $31 \mu \mathrm{g} / \mathrm{dl}(1.5 \mu \mathrm{mol} / \mathrm{l})$ but showed only a small change in isotope ratio (1.192) from the previous February $(1 \cdot 191)$ and August $(1 \cdot 187)$. At this time his urinary excretion of $\mathrm{Pb}$ and $\mathrm{Sn}$ was 25 and 6 $\mu \mathrm{g} / 24 \mathrm{~h}$, respectively $(0.21 \mu \mathrm{mol}$ and $0.05 \mu \mathrm{mol})$. Six unexposed subjects had excretions of $\mathrm{Sn}$ ranging from 1 to $6 \mu \mathrm{g} / 24 \mathrm{~h}(8-48 \mathrm{nmol} / 24 \mathrm{~h})$. When he returned with high blood $\mathrm{Pb}$ in September 1980 the isotope ratio was 1.240 and his urinary $\mathrm{Sn}$ was raised.

Metal recovered from his stool contained many curled, deeply striated shavings. All were somewhat corroded. Associated with the metal were grains of garnet. Shavings of $\mathrm{Cu}$, conspicuous in the material 


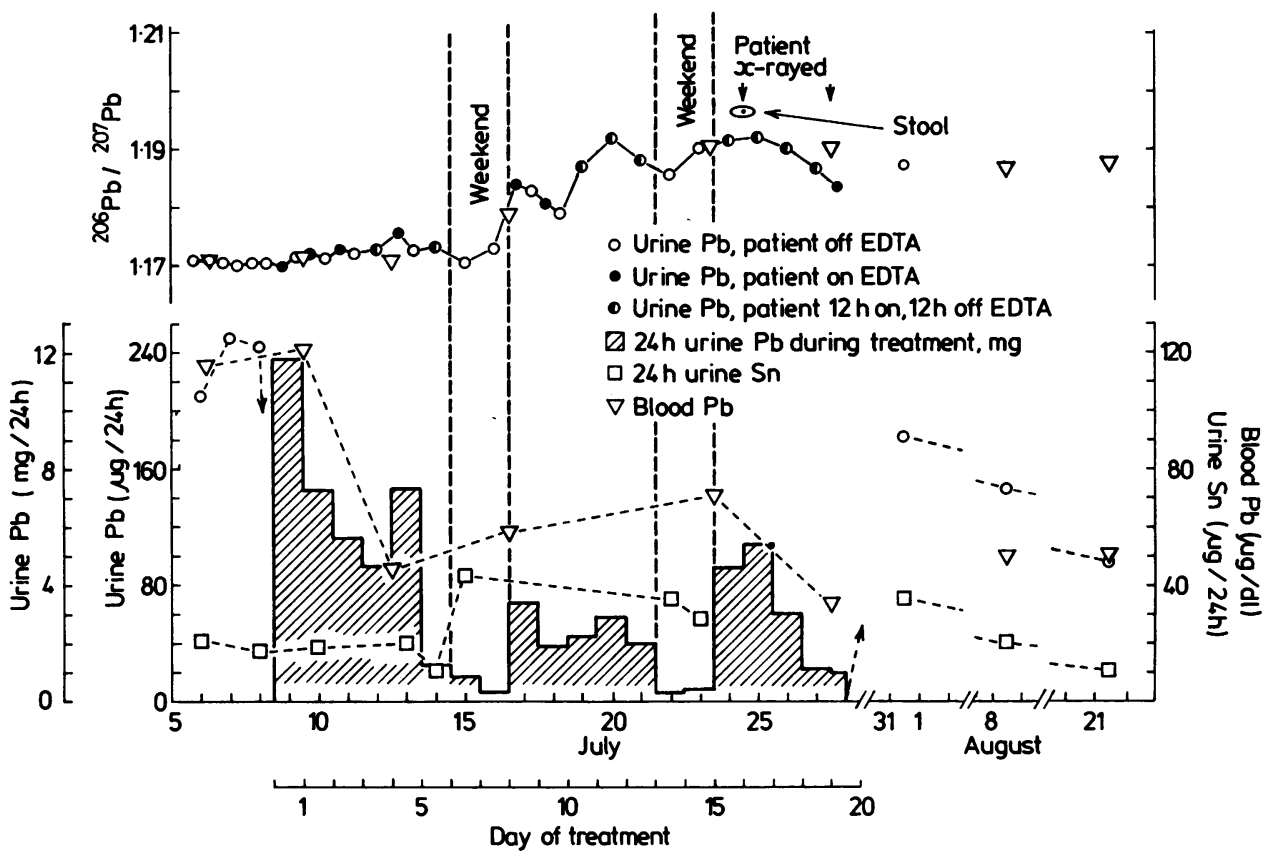

Fig 1 Upper portion: Ratio $200 \mathrm{~Pb} / 207 \mathrm{~Pb}$ in blood and urine before, during, and immediately after chelation therapy. Isotope ratio of $\mathrm{Pb}$ in solder containing stool sample is also shown. Lower portion: Concentration of $\mathrm{Pb}$ in blood and urine and concentration of $\mathrm{Sn}$ in urine over same period. Note a different scale used to represent urinary $\mathrm{Pb}$ during chelation therapy and that after $28 \mathrm{July}$ time scale is not continuous.

from his badge, were also present. Analysis of the bulk material gave $18 \% \mathrm{Sn}$ and $82 \% \mathrm{~Pb}$. During the first series' observations the fraction of $\mathrm{Pb}$ in the patient's serum changed from $0.3 \%$ of whole blood $\mathrm{Pb}$ to $1.6 \%$ as the whole blood concentration changed from $31 \mu \mathrm{g} / \mathrm{dl}(1.5 \mu \mathrm{mol} / \mathrm{l})$ to $116 \mu \mathrm{g} / \mathrm{dl}(5.6 \mu \mathrm{mol} / 1)$. The second time his blood $\mathrm{Pb}$ was raised the fraction was larger and variable. A plot of $\mathrm{Pb}$ in serum

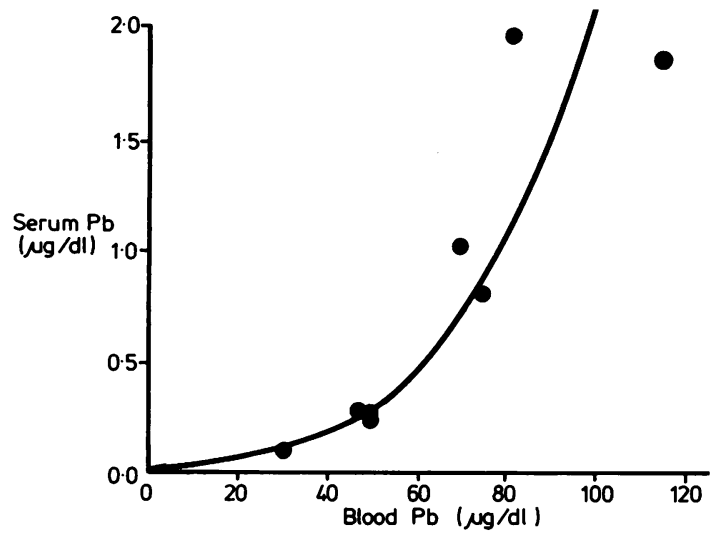

Fig 2 Plot of serum Pb against whole blood Pb. against $\mathrm{Pb}$ in blood is shown in fig 2 . Blood taken 12 hours after administration of EDTA contained close to normal ratios of serum $\mathrm{Pb}$ to blood $\mathrm{Pb}$. In one sample taken three hours after administration of EDTA had begun $6.4 \%$ of the $\mathrm{Pb}$ was contained in serum.

The concentration of $\mathrm{Pb}$ in cerebrospinal fluid varied between $39 \%$ and $86 \%$ of the serum concentration. Apart from the fact that the concentration of $\mathrm{Pb}$ in cerebrospinal fluid was consistently less than that in serum, no correlation appeared to exist.

The patient's renal clearance of $\mathrm{Pb}$ from serum ranged from $5.1 \mathrm{ml} / \mathrm{min}$ to $36 \mathrm{ml} / \mathrm{min}$, the high value being obtained 11 days after the end of chelation therapy.

\section{Discussion}

\section{SOURCE OF LEAD INTOXICATION}

The change in isotope ratio during the third period of treatment is clearly attributable to the ingestion of $\mathrm{Pb}$ with a different isotope ratio from that stored in his tissues. The time of the change and the known two to three day transit of material through the alimentary tract $^{+}$suggest that the patient ingested the solder 
when home for the weekend. Noting that a rapid change in isotope ratio had occurred the previous weekend and that increases in isotope ratio accompanied increases in $\mathrm{Pb}$ excretion, we suspect that the patient ingested solder on that weekend also, and on days 5 and 12 . Furthermore, the raised $S n$ in his baseline urines and in his urine of September 1980 suggested that the source of his lead intoxication on both occasions was also solder, even though he had not worked since January 1979. The isotope ratios, however, show that none of these three sources of solder was the same.

The baseline ${ }^{216} \mathrm{~Pb} /{ }^{207} \mathrm{~Pb}$ of $1 \cdot 171$ is unusually low for $\mathrm{Pb}$ in the Dallas environment, although it is at the lower end of the range, $1 \cdot 167$ to $1 \cdot 310$, that we have measured from soldered cans. Solder purported by the patient to have been used in his work had a ratio of 1.217 and filings caught between his identification badge and its plastic cover had a ratio of $1 \cdot 194$. Blood obtained from his workmate contained $16 \mu \mathrm{g} \mathrm{Pb} / \mathrm{dl}$ $(0.77 \mu \mathrm{mol} / \mathrm{l})$ with a ratio of $1 \cdot 196$. Thus we cannot match the $\mathrm{Pb}$ in his blood with industrial exposure. Exposure at home seems unlikely as his wife's blood contained $12 \mu \mathrm{g} \mathrm{Pb} / \mathrm{dl}(0.58 \mu \mathrm{mol} / \mathrm{l})$ with a ratio of $1 \cdot 199$. Unfortunately, we did not measure the isotope ratio of the blood sample of 15 May, but, to obtain an estimate of how long his blood had so low a ratio, we obtained in August 1979 clippings of his toenails. These contained $9 \mathrm{ppm} \mathrm{Pb}$ with a ratio of $1 \cdot 192$. Given that nails grow at $0 \cdot 1 \mathrm{~mm} / \mathrm{day},{ }^{5}$ this ratio would have been that of his blood six to nine months earlier, or at about the time he was last working. We conclude that the patient acquired $\mathrm{Pb}$ with the ratio of $1 \cdot 171$ only a short time before he came to our notice in May 1979.

Taken together, the points discussed in the preceding paragraphs suggest to us that the patient had deliberately ingested solder before admission to hospital, during treatment, and a year after treatment. He has, however, consistently denied having done so.

\section{ACTION OF EDTA ON THE SKELETON}

Hammond et $\mathrm{l}^{6}$ and Hammond ${ }^{7}$ have shown that EDTA removes $\mathrm{Pb}$ from soft tissue in an indirect manner, chelating with a mobile pool of $\mathrm{Pb}$ in bone, which is then rapidly replenished by $\mathrm{Pb}$ from blood and other soft tissue. In terms of their model the isotope ratios of $\mathrm{Pb}$ in the 12-hour urine samples (fig 1), when administration of EDTA started, represent those of the skeletal pool. The substance EDTA is rapidly cleared from plasma, so that the 12-hour urine samples collected when administration of EDTA had ceased tend to have lower isotope ratios, because they contain some $\mathrm{Pb}$ with the baseline isotope ratio, which began to enter plasma from the erythrocytes and the soft tissues. Samples taken more than 12 hours after administration of EDTA, such as blood on day 7 and urine on day 9 , have the baseline isotope ratio and are samplings of soft tissue $\mathrm{Pb}$ in transit to the skeleton. Once the patient began ingesting solder, the EDTA bound with both skeletal $\mathrm{Pb}$ and the $\mathrm{Pb}$ entering the plasma from his gut; while EDTA was not being administered, $\mathrm{Pb}$ from solder continued to enter his plasma and together with soft tissue $\mathrm{Pb}$ replaced the $\mathrm{Pb}$ removed from his skeleton. The result was that by the end of the treatment the patient had replaced $\mathrm{Pb}$ of one isotope ratio in his skeletal pool with $\mathrm{Pb}$ of another isotope ratio, which thereafter dominated the isotope ratio of his blood. The blood sample of day 20 is conspicuous for having an isotope ratio greater than that of urine. Since this sample was taken 12 hours after administration of EDTA, this blood $\mathrm{Pb}$ is interpreted to be newly absorbed $\mathrm{Pb}$ from solder mixed with some soft tissue $\mathrm{Pb}$.

One of the patient's premolars contained $56 \mathrm{ppm}$ $\mathrm{Pb}$ with an isotope ratio of $1 \cdot 207$, which is probably representative of the $\mathrm{Pb}$ in his compact bone, as the half life of $\mathrm{Pb}$ in that region of his skeleton is of the order of tens of years. The constancy of the isotope ratio $(1 \cdot 171)$ of $\mathrm{Pb}$ in his urine during the first week of chelation indicates that EDTA did not chelate a significant fraction of the $\mathrm{Pb}$ bound in compact bone. This observation, taken with the decreasing amounts of $\mathrm{Pb}$ in his urine, suggests that the chelatable pool is of limited size and near constant in isotope ratio, the same conclusion as reached by Hammond. ${ }^{n}$ Interestingly the ratio in his tooth, which reflects the $\mathrm{Pb}$ to which he was exposed 40 to 50 years ago, is somewhat greater than that found in the blood of current Dallas residents.' From observations on seasonal changes in $\mathrm{Pb}$ isotope ratios in blood Manton $^{2}$ has inferred such a relationship.

SIGNIFICANCE OF LEAD IN SERUM AND CSF Our result that the fraction of $\mathrm{Pb}$ in serum rises with blood $\mathrm{Pb}$ concentration does not support the findings either of Cavalleri et al $^{\star}$ who reported plasma $\mathrm{Pb}$ to be approximately constant at $3 \%$ of whole blood or of Rosen et al who reported plasma $\mathrm{Pb}$ to be independent of whole blood concentration. In the case of the patient reported here quadrupling of blood $\mathrm{Pb}$ brought about a sixteen-fold increase in serum $\mathrm{Pb}$, which indicates that the toxicity of $\mathrm{Pb}$, measured by the level of $\mathrm{Pb}$ in serum, rises as a very steep function of blood $\mathrm{Pb}$ concentration (fig 2). DeSilva ${ }^{10}$ has reported plasma $\mathrm{Pb}$ concentrations and plasma $\mathrm{Pb}$ to blood $\mathrm{Pb}$ fractions similar to those found in this laboratory. ${ }^{3}$ Her plot of plasma $\mathrm{Pb}$ concentration versus erythrocyte $\mathrm{Pb}$ concentration is similar in shape to ours. We suggest that her data 
would have been better fitted by a power function passing through the origin than by the straight line with a negative intercept that she fitted.

It must be emphasised that our patient showed none of the classic signs of $\mathrm{Pb}$ intoxication. We interpret this to mean that he had only recently acquired a high blood $\mathrm{Pb}$ concentration and that the haematological and neurological effects of $\mathrm{Pb}$ take time to manifest themselves in adults.

In absolute terms the fraction of $\mathrm{Pb}$ in the patient's cerebrospinal fluid is somewhat higher than the figure of $0.46 \pm 0.20$ obtained in this laboratory from patients with normal blood $\mathrm{Pb}$ concentrations, ${ }^{3}$ with the implication that at high blood $\mathrm{Pb}$ the blood-brain barrier becomes less effective in keeping $\mathrm{Pb}$ out of cerebrospinal fluid. The variability observed probably reflects slow equilibration between $\mathrm{Pb}$ in plasma and $\mathrm{Pb}$ in cerebrospinal fluid. Although the concentration of $\mathrm{Pb}$ in the patient's cerebrospinal fluid was as high as 20 times normal, he displayed no central nervous system deficits that could unequivocally be attributed to $\mathrm{Pb}$ intoxication.

Measurement of $\mathrm{Pb}$ in serum and cerebrospinal fluid will only be useful clinically once a correlation with toxic effects has been established. In a case of plumbism from a retained bullet, ${ }^{11}{ }^{12}$ where it can be certain that the patient maintained high blood $\mathrm{Pb}$ for a long time, the patient suffered severe motor neuropathy with a serum $\mathrm{Pb}$ of $3.3 \mu \mathrm{g} / \mathrm{dl}(0.16 \mu \mathrm{mol} /$ 1) or 25 times normal. At the same time his cerebrospinal fluid $\mathrm{Pb}$ was $2.6 \mu \mathrm{g} / \mathrm{dl}(0.13 \mu \mathrm{mol} / 1)$ or 64 times normal, yet he showed no severe central nervous system deficits. This single case suggests that serum $\mathrm{Pb}$ is a more critical parameter to monitor than cerebrospinal fluid $\mathrm{Pb}$.

\section{RENAL CLEARANCE OF LEAD}

The range of renal clearance observed, $5 \cdot 1-36 \cdot 0 \mathrm{ml} /$ $\mathrm{min}$, is in accord with the findings of Vander et al ${ }^{13}$ that the greater part of $\mathrm{Pb}$ filtered by the kidney is reabsorbed. Nevertheless, the high value of $36 \mathrm{ml} /$ min requires explanation.

Inspection of the data in the table shows this measurement to have been made 11 days after the end of chelation therapy at a time when the patient's urinary excretion of $\mathrm{Pb}$ was steadily decreasing while his serum $\mathrm{Pb}$ remained constant. Over the period of observation his creatinine clearance remained constant at $68 \mathrm{ml} / \mathrm{min}$, ruling out change in glomerular filtration rate. The isotope ratio of $\mathrm{Pb}$ in the urine of 31 July (day 22) shows that the $\mathrm{Pb}$ excreted was not $\mathrm{Pb}$ with the baseline isotope ratio that had been sequestered in the renal tubular cells. The excretion of the divalent elements, $\mathrm{Ca}$ and $\mathrm{Mg}$, whose metabolism might have been perturbed by $\mathrm{Na}_{4}$ EDTA were in the normal range and did not correlate with $\mathrm{Pb}$ excretion.

The explanation seems to lie in an interaction of $\mathrm{Pb}$ and Sn. Our data show that the excretion of these elements was mutually dependent for the three weeks after chelation therapy (fig 1) and that the ratio of urinary $\mathrm{Sn}$ to serum $\mathrm{Pb}$ gives a fairly consistent pattern of following the $\mathrm{Pb}$ clearance (table). There are three possibilities regarding such an interaction: Sn may (1) promote the tubular secretion of $\mathrm{Pb}$; (2) inhibit its tubular reabsorption; or (3) increase its ultrafilterability. Vander et $^{1 / 4}$ have shown that the uptake of $\mathrm{Pb}$ by renal slices in vitro is inhibited by $\mathrm{Sn}^{4+}$. In such experiments, however, the uptake is through the basolateral and not the luminal membrane of the renal tubular cells, with the implication that the effect of Sn would be to inhibit the tubular secretion of $\mathrm{Pb}$. We therefore feel that the first possibility is unlikely. To evaluate the second and third, the absolute concentrations of ultrafilterable $\mathrm{Sn}$ and $\mathrm{Pb}$ in plasma must be known. Our attempts to measure these have thus far been unsuccessful. We found Amicon ultrafiltration cones to contain large and variable amounts of $\mathrm{Pb}(80-190 \mathrm{ng}$ or $0.4-0.9$ $\mathrm{nmol})$ and the amount of $\mathrm{Sn}$ in serum $(<1 \mu \mathrm{g} / \mathrm{dl}$ or $0.08 \mu \mathrm{mol} / \mathrm{l})$ is at the limit of measurement by conventional stable isotope dilution methods.

\section{Conclusions}

(1) In the United States where the $\mathrm{Pb}$ used in industry comes from many mines differing in geological age isotopic analysis may be used to identify $\mathrm{Pb}$ from different sources. This technique may be especially useful where litigation is concerned.

(2) The isotopic data support the model that EDTA acts upon a finite chelatable reservoir of $\mathrm{Pb}$ in the skeleton.

(3) Before serum $\mathrm{Pb}$ and cerebrospinal fluid $\mathrm{Pb}$ concentrations may be used clinically, correlation with toxic effects must be established. The assays, however, are difficult and are probably beyond the capability of all but a few clinical laboratories.

(4) Although the daily absorption of Sn from the diet is probably not large, ${ }^{15}$ the small quantity absorbed may none the less have the beneficial effect of increasing $\mathrm{Pb}$ excretion.

We thank James Knochel for advice and Julio Barroto and Marla Hintz for technical help. This work was supported by the Muscular Dystrophy Association, Inc.

\section{References}

' Rabinowitz MB, Wetherill GW, Kopple JD. Kinetic analysis of 
lead metabolism in healthy humans. J Clin Invest 1976;58:26070.

2 Manton WI. Sources of lead in blood: identification by stable isotopes. Arch Environ Health 1977;32:149-59.

${ }^{3}$ Manton WI, Cook JD. Lead content of cerebrospinal fluid and other tissue in amyotrophic lateral sclerosis. Neurology $(N Y)$ 1979;29:121.

${ }^{4}$ Burkitt DP, Walker ARP, Painter NS. Effect of dietary fibre on stools and transit-times, and its role in the causation of disease. Lancet 1972;ii: 1408-11.

${ }^{5}$ Bean WB. Nail growth: thirty five years of observation. Arch Intern Med 1980;140:73-6.

- Hammond PB, Aronson AL, Olson WC. The mechanism of mobilization of lead by ethylenediaminetetraacetate. $J$ Pharmacol Exp Ther 1967;18: 196-206.

7 Hammond PB. The effects of chelating agents on the tissue distribution and excretion of lead. Toxicol Appl Pharmacol 1971;18:296-310.

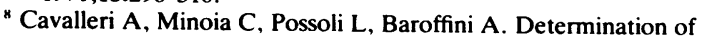

plasma lead levels in normal subjects and in lead-exposed workers. Br J Ind Med 1978;35:21-6.

' Rosen JF, Zarate-Salvador C, Trinidad EE. Plasma lead levels in normal and lead intoxicated children. J Pediatr 1974;84:45-8.

${ }^{10}$ deSilva PE. Determination of lead in plasma and studies on its relationship to lead in erythrocytes. Br J Ind Med 1981;38:20917.

"Linden MA, Manton WI, Stewart RM, Thal ER, Feit H. Lead poisoning from retained bullets: pathogenesis, diagnosis and management. Ann Surg 1982;195:305-13.

12 Manton WI, Stewart RM, Tindall TSA, Feit H. Parainfectious encephalopathy. N Eng J Med 1982;306:112.

${ }^{13}$ Vander AJ, Taylor DL, Kalitis K, Mouw DR, Victery W. Renal handling of lead in dogs. Am J Physiol 1977;233:F532-8.

${ }^{14}$ Vander AJ, Mouw DR, Cox J, Johnson B. Lead transport by renal slices and its inhibition by tin. Am J Physiol 1979;236F:373-8.

is Byrne AR, Kosta L. On the vanadium and tin contents of human blood. Sci Total Environ 1979;13:87-90. 